DOI: 10.20472/AHC.2018.003.004

ARBENITA SYLEJMANI NIMANI

Phd Candidate, Univesity of Tirana, Faculty of Social Science, Sociolgy, Kosovo

\title{
HOW MUCH INFLUENCE DOES MEDIA ON VOTING FOR POLITICAL CANDIDATES IN KOSOVO?
}

\begin{abstract}
:
The purpose of this paper is to identify how much media generally influences the voting process of political candidates during the election campaign. Also, this paper aims to see what other causes might exist that fewer women compete in politics, and why these women are not getting elected? This paper has utilizes used a combination of qualitative and quantitative methods. Qualitative method includes the analysis of the content of the newspaper's front page, and the realization of 20 in depth interviews with journalists. While as a quantitative method a survey with questionnaires was used which were filled by 200 citizens of Pristina, Kosovo.

In the last local elections held on October 22, 2017 in Kosovo, for 38 Kosovo municipalities, there were 196 men and 8 women candidates running for the local elections. But no woman managed to win the local elections. Even in the previous elections we had a woman who was voted as a mayor, but now we have none. It turns out that on the front page of newspapers men are mentioned much more than women during the election campaign. For example, the daily newspaper Koha Ditore, as the most widely read newspaper, during the election campaign; men politicians who run for mayor were quoted what they said 32 times in front page, while women who also run for mayor quoted only 2 times. Also, the other daily newspaper Zëri had cited men politicians what they promised during the election campaign 27 times while women only twice.
\end{abstract}

\section{Keywords:}

women, men, media, newspaper, election, campaign, voted. 


\section{Introduction}

The purpose of this paper is to identify how much the media generally influences the voting process of political candidates during the election campaign. Also, this paper aims to see what other causes might be for having fewer women who run in politics, and fewer who win local elections in Kosovo?

This paper has used a combination of qualitative and quantitative methods. Qualitative method includes the analysis of the content of the newspaper's front page, and the realization of 20 in depth interviews with journalists. The period that analyzed newspapers is: $21.09 .2017-30.09 .2017$. The front pages of the newspapers were analyzed for a period of one week during the electoral campaign. Local elections were held on October 22, 2017, and the election campaign began on 21.09.2017. While using the questionnaire as a quantitative method, the questionnaire was filled out by 200 citizens of Pristina, with over 18 years old, to ask what they think might be the cause we have fewer politically-valued women, and if the media can be one of the potential shifts.

In the last local elections held on October 22, 2017, for 38 Kosovo municipalities, there were 196 men and 8 women candidates running for the local elections. But no woman managed to win the local elections as a mayor of municipality. Even in the previous elections we had a woman who was voted mayor, but now we have none. The analysis of newspapers was made for the three most widely read local newspapers in Kosovo. It turns out that on the front page men are mentioned much more than women during the elections campaign. For example, the daily newspaper Koha Ditore, as the most widely read newspaper, during the election campaign; men politicians who run for mayor were quoted what they said 32 times in front page, while women who also run for mayor quoted only 2 times. Also, the other daily newspaper Zëri had cited men politicians what they promised during the election campaign 27 times while women only twice. On the other hand, citizens felt that it is not just the Media's fault because there are few voted women, it was believed that the main cause are the political parties who are the ones who favor men. Moreover, in interviews with journalists it is learned that not only the media, and newspaper is guilty, because the political campaign part are paid by the political parties and they decide which candidates to write about, and it is not the media that decides.

\section{Methodology}

This paper has used a combination of qualitative and quantitative methods. Qualitative method includes the analysis of the content of the newspaper's front page, and the realization of 20 in depth interviews with journalists. The period that analyzed newspapers is: 21.09.2017 -30.09.2017. Local elections were held on October 22, 2017, and the election campaign began on 21.09.2017. The first pages of the newspapers were analyzed for a period of one week during the electoral campaign. While using the 
questionnaire as a quantitative method, the questionnaire was filled out by 200 Pristina citizens, with over 18 years old, to ask what they think might be the cause we have few politically-valued women, and if the media can be one of the potential shifts.

This analysis of the articles of three Kosovo daily newspapers was done using newspapers, such as: Koha Ditore, Kosova Sot, and Zëri. These newspapers are selected because, according to a survey conducted by Index-Kosovo in Kosovo in 2008, the most widely read newspapers in Kosovo are: Koha Ditore 36\%. The newspaper Kosova Sot follows with 35\%. And, Zeri's newspaper by $8 \%$. (Index, 2008). But in this analysis there is no analysis of the newspaper Kosova Sot, since it has not been found that the first page in this newspaper was written for both men and women competing during these elections.

The analysis of newspaper was realized in Excel program.

\section{Media as an obstacle or empowerment tool?}

In most widely read newspapers in Kosovo, in front page men politician are mentioned much more than women politician during the election campaign. As shows figures 1 and 2 , the newspapers did not have the same gender coverage during the election campaign for running candidates. In figure 1, in the most widely read newspaper 'Koha Ditore', 32 men were mention and quoted in the front page during the election campaign, while women are mentioned only 2 times.

\section{Figure 1}

\section{How much women and man politician mention in the front page of newspaper Koha Ditore?}

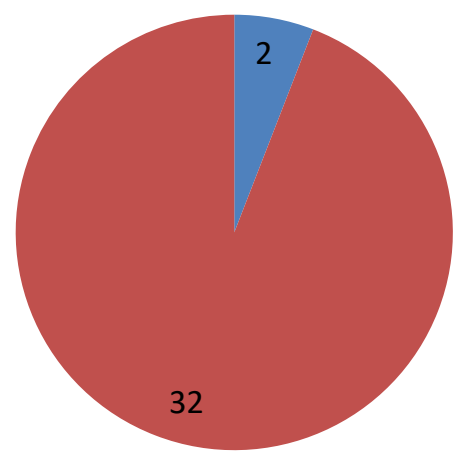

Wimen politician

Man politician

Source: daily newspaper 'Koha Ditore', Prishtinë, Kosovë. 
The media should acknowledge the voice of women, and during the election campaign the media should ensure gender sensitive coverage in the elections. Gender-sensitive coverage should remove negative stereotypes for women and highlight the woman's portrait as the country's effective leader (Sindhu \& Murugan, 2017). The role of mass media is considered important, as the media is a source of information for every citizen. People receive political news and information through TV, newspaper, magazine, radio and web pages. Media plays an important role in determining how women are viewed in politics and decision making and how they are perceived by society. The media is not only playing an important role, but also reflecting on these values, because it plays the role of educator. By playing a role in creating awareness in society, there must be a proactive role.

Also, figure number 2 in the newspaper 'Zëri', in the front page of newspaper 27 men was mentioned while only 2 women were mentioned on the same page. During these analyses' it was noted that the women who run during the election campaign are usually quoted in the newspaper regarding what the leader of the party promised, and it was not quoted what the candidate himself promised. But during interviews with journalists, it is claimed that political parties are the ones who pay the part for the election campaign and are not the newspapers that decide. Also, in the survey conducted with citizens, the media are not considered guilty of having fewer voters, but the blame is assigned on the political party that decides who will go on the newspapers and the media in general.

\section{Figure 2}

\section{How much women and men politician mention in the front page of newspapers Zëri?}



Women po

Man politic

Source: daily newspaper 'Zëri', Prishtinë, Kosovë. 
According to the World Bank, in 2015, worldwide women account $49,54 \%$ of world's population (2015). However, they do not hold half of their positions in politics. For example, at world level, women account in politics $23,5 \%$ of world parliaments. Also, in Kosovo 30\% of seats in Parliament belongs to women. In the last local elections held on October 22, 2017, for 38 Kosovo municipalities, there were 196 men and 8 women candidates running for the local elections. But no woman managed to win the local elections. Moreover, as figure no. 3 shows that $90 \%$ of citizens considers that there should be more women in politics.

\section{Figure 3}

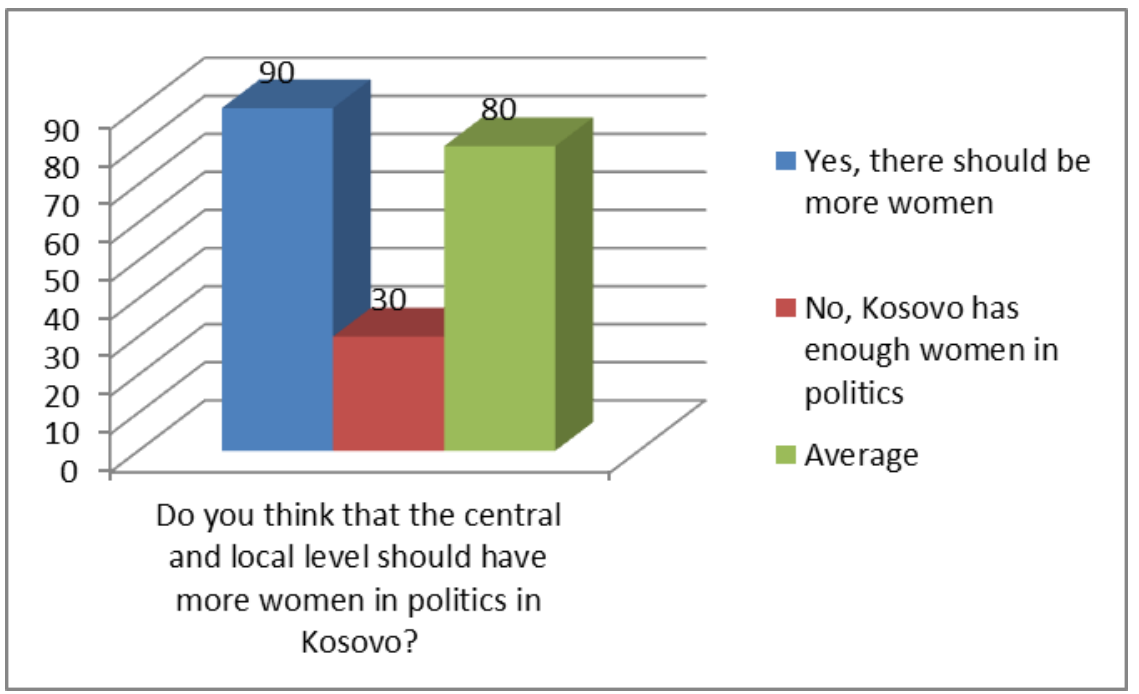

As it shows in figure no. 3 respondents believe that there should be more women in politics, in local and central level in Kosovo.

Even today, we cannot say that women in politics have equal treatment in relation to their peers. Today, women in politics receive a lot of attention regarding their appearance, family and personality. Moreover, today sexism still exists, for example, as it can be seen from the image number one. 


\section{Image 1}

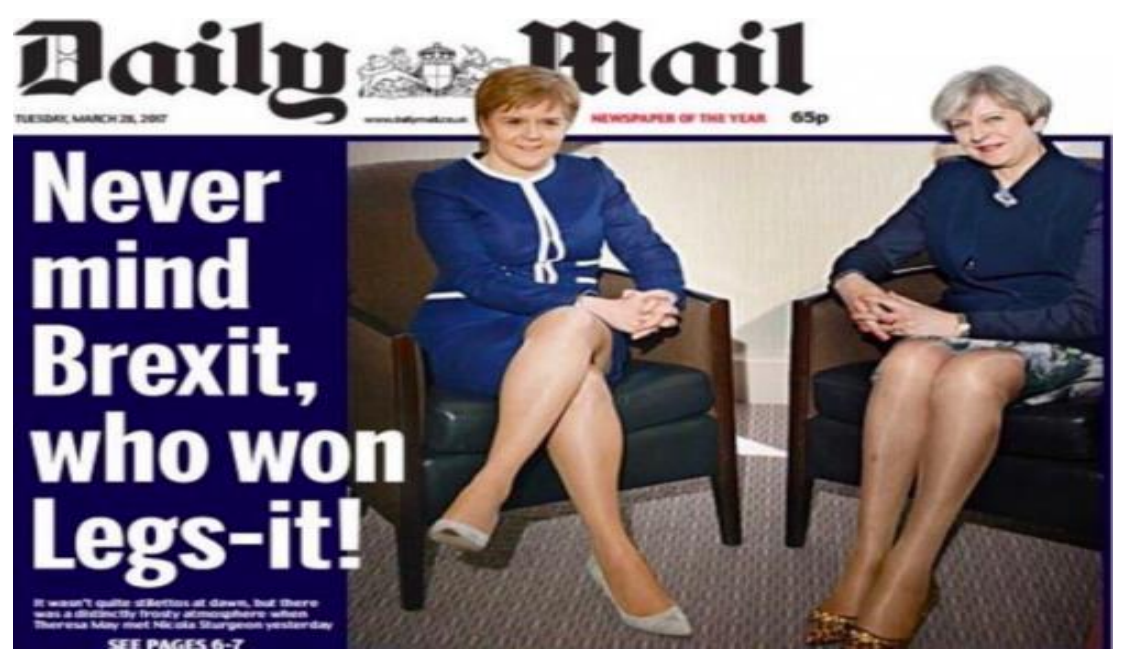

Source: the guardian https://www.theguardian.com/media/2017/mar/28/daily-mail-legs-it-front-page-sexist

When women are head of the states, still newspapers doesn't write for their political performance. Moreover, many scholars agree that there is a big difference between what media covers for women and men politicians. This distinction has been observed by researchers Flower and Lawles in 2009, where they conducted research between 1920 and 1990 during the electoral campaign for the Governor's election. These researchers considered how candidates choose to portray themselves and how these images were followed by the media, concluding that the media exert a strong influence over the type of policy and reach voters and thus refocus gender stereotypes (2009). The media returned women politicians, models for fashion style rather than focusing on real policy and policy issues (Norris, 1997).

Study, from figure number 4 reveals that media writes with sexism where $60 \%$ of respondents agreed. Respondents more agreed that newspapers should write more often articles that empower women in politics. Another percentage of respondents have highlighted that not always newspapers write with sexism. 


\section{Figure 4}

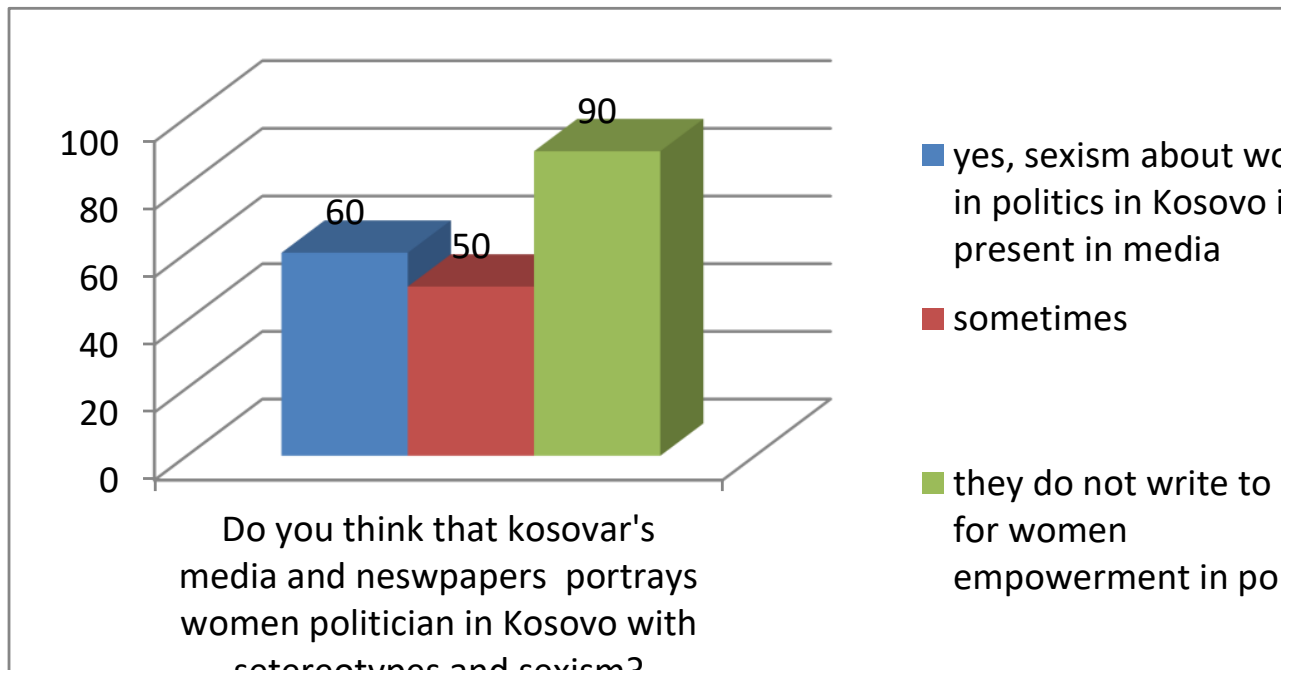

According to the figure number 5 , respondents don't consider media as the only important factor that leads citizens doesn't vote women. The reason why we have fewer women voted, $70 \%$ of respondents believe on women themselves because they are not enough active because they lack political ambition.

\section{Figure 5}

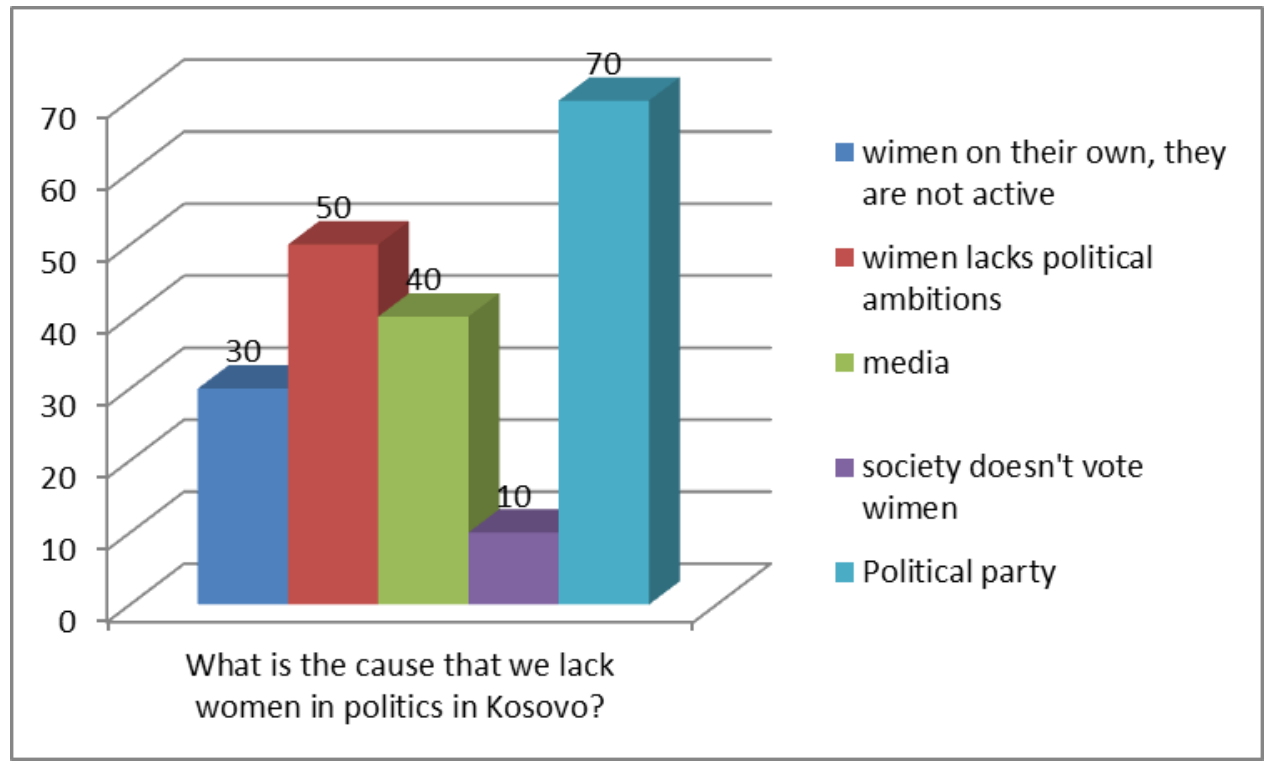

Furthermore, researchers Lawless and Fox, in their research in 2008, bring the reasons why women are less represented in politics, arguing that women are less inclined to have political ambitions than men in politics. According to these authors, this reason was the same in 2001. Similarly to this argument, the other theoretical view argues that women generally when they run, they win elections at a higher level than men. Also, there is no reason why women do not run enough. But the problem lies in the fact that we have a 
lack of ambitions at women. Lack of ambition comes as a result of the lack of selfconfidence that keeps women in politics (Kerpen, 2017).

\section{Conclusions}

This research shows that during the election campaign of the 2017 local elections, newspapers had cited more men than women. According to the results of this research, political parties remain the largest contributors to the fewer voted women, even in the media. In Kosovo, the largest political parties are led by men, and most journalists declare that the political party pays for the election campaign articles, and decides who to mention more, so it is not the media that decides. But this does not detract media from the responsibility, especially the newspapers, since apart from the fact that it is paid by political parties for election campaign, it may write in other section of newspaper any articles that would call for more women to vote, and that article could anonce in the front page, in order to get more reader attention. Moreover, respondents consider that there should be more articles in women-empowering newspapers, because this will have the effect of having more voters. The lowest level of women's presence in the media can affect the fewer voters. Lack of ambition remains another finding because we have few women in politics.

\section{References}

Bank, T. W. (2015). World Bank staff estimates based on age/sex distributions of United Nations Population Division's World Population Prospects. Retrieved from https://data.worldbank.org/indicator/SP.POP.TOTL.FE.ZS?end=2015\&start=1960\&view=chart

Flower, L., \& Jennifer, L. (2009). Looking for Sex in All the Wrong Places. Press Coverage and dhe Electoral Fortunes of Gubernatorial Candidates, Perspectives on Politics.

G.Bystrom, D., Banwart, M. C., Kaid, L. L., \& A.Robertson., T. (2004). Gender and Candidate Communication (First Edition ed.). New York; London: Routledge.

Index, K. (2008). Media Picture in Kosova. Prishtinë: Index Kosova.

Kerpen, C. (2017, November 24). women@forbes. Retrieved from Forbes: https://www.forbes.com/sites/carriekerpen/2017/11/14/run-women-run/\#2f4ca907192a

Norris, P. (1997). Media and Politics. New York: Oxford University Press.

Sindhuja, P., \& Murugan, K. (2017). Factors impeding women's political participation. International Journal of Applied Research, 563-565. Retrieved from http://www.allresearchjournal.com/archives $/$ year=2017\&vol=3\&issue=4\&part=I\&Articleld=3590 